\title{
Integration of Multicultural Education into English Teaching and Learning: A Case Study in Liaoning Police Academy
}

\author{
Li Wei \\ Liaoning Police Academy, Dalian, China
}

\begin{abstract}
The multicultural education has become the educational reality all over the world with the deepening and widening of the international and interpersonal communication in economic and cultural spheres. More and more people regardless of race, nationality, language, and culture come together to share the human cultures and make spiritual communication. How to promote smooth and successful interpersonal communication among different peoples, and how to enhance mutual respect and understanding among diverse cultures? The paper takes these issues into account and aims to find appropriate answers. Based on the fundamental theories of multiculturalism and actual practices of multicultural education in America and Canada, the paper discusses the practice and significance of multicultural education in English class in Liaoning Police Academy. This creative multicultural plan adheres to four basic principles, carrying out unique warm-up and after-class activities, such as Cultural Journey Series, Native American's Cultural Nurturing, Cultural Immersion in Growing-up QQ English Group. After one and a half years' multicultural training, 20 minority students build sufficient self-confidence, introducing their respective minority cultures to other students and learning a lot of Chinese traditional cultures and Western cultures. The Han students also reap bountiful harvest, taking active interest in other cultures and mastering basic knowledge and skills to cope with cross-cultural communication. As the accumulation of multicultural educational experience and reflection upon its strengths and limitations are continuously enriched, this multicultural education program will be more efficient, diversified and fascinating.
\end{abstract}

Index Terms - multiculturalism, multicultural education, English class, cross-cultural communication

\section{INTRODUCTION}

The first decade of the $21^{\text {st }}$ century has displayed the new trend that more and more people are frequently involved in the activities of cross-cultural communication. This cross-cultural communication between two persons from different countries or ethnic groups is going on in diverse living space ranging from international negotiation table, professional situation to classroom environment. The international experiences indicate that Multiculturalism and multicultural education have become the national policy or the educational routine in such countries constituted by multiple peoples as America, Canada, and Australia. This educational strategy on the basis of Multiculturalism effectively avert interpersonal contradictions and conflicts due to cultural differences or misunderstanding, contributing to creating friendly, trustworthy and harmonious working and learning atmosphere. China is a country with long history of multiethnic habitation and interaction dating back to Qin dynasty. Although China didn't enact the formal law or make the policy as Canadian Multiculturalism or American cultural pluralism, it did implement and carry forward the principles of multiethnic equality, multicultural exchange, mutual learning and common development. The paper just describes vividly the real experience of the author's multicultural education in and after her English class, giving us a good example to carry out multicultural education via English immersion and sparking the profound thinking about the appropriate approaches of multicultural education in China.

\section{Multiculturalism and Multicultural EduCATion: American ANd CANADian EXPERIENCES}

\section{A. The Multiculturalism in America and Canada}

Individuals who have competencies to operate successfully in two or more different cultures are bicultural or multicultural. Multiculturalism is states in which one has mastered the knowledge and developed the skills necessary to feel comfortable and communicate effectively. (Hoopes, 1979) Goodenough (1976) defined multiculturalism as the "normal human experience." All Americans participated in multicultural group, thus they can be proficient in multiple systems for perceiving, evaluating, believing, and acting according to different cultural environments in which they are participating. Banks (1981) suggested that multiethnic and multicultural education programs can help students expand their cultural competencies to include those required to function effectively in microcultures (subsocieties within the United States contain cultural elements, institutions, and groups who share cultural patterns that are not common to the 
U.S. macroculture, or mainstream culture. The cultures of these groups are called microcultures) in which they are not members.

Given many Canadian domestic circumstances, the leader of Liberal Party brought forth the Multiculturalism as the national policy in the early 1970s in Canada. Its initial objective was to integrate new Canadians into the mainstream through cultural adjustment and mutual understanding. The Canadian government would strengthen the solidarity of the Canadian people by enabling all Canadians to participate fully and without discrimination in defining and building the nation's future. (Wei, 2012) Multiculturalism has been developed from its initial folkloric multiculturalism focusing on equality of status, Canadian identity, personal choice and protection of individual rights to the second stage of institutional multiculturalism stressing social justice and institutional accommodation through removal of discriminatory barriers. The third stage is civic multiculturalism which hopes to foster a sense of belonging and a shared sense of Canadian identity. (Cardozo, 1997) Table 1 (Fleras and Elliott,1999) presents us with the detailed description of the Multiculturalism development in different stages.

TABLE 1

THREe Stages OF Multiculturalism POLICY

\begin{tabular}{|l|l|l|l|}
\hline Three Stages of Multiculturalism & $\begin{array}{l}\text { Folkloric Multiculturalism } \\
(1970 s)\end{array}$ & $\begin{array}{l}\text { Institutional Multiculturalism } \\
(1980 \mathrm{~s})\end{array}$ & $\begin{array}{l}\text { Civic } \\
(1990 \mathrm{~s})\end{array}$ \\
\hline Focus & Celebrating differences & Managing diversity & Society building \\
\hline Reference point & Culture & Structure & Community \\
\hline Mandate & Ethnicity & Race relations & Citizenship \\
\hline Magnitude & Individual adjustment & Structural accommodation & Social participation \\
\hline Problem source & Racial prejudice & Systemic discrimination & Social exclusion \\
\hline Problem solution & Cultural sensitivity & Employment equity & Social inclusion \\
\hline Key metaphor & Mosaic & Level playing field & belonging \\
\hline
\end{tabular}

All in all, as a national policy to mitigate the interethnic contradiction and promote multicultural exchange and understanding, Multiculturalism has attained its original goal and continues to add new connotation into its core ideology and new strategy into its concrete policy with the social progress and demographic change in Canada.

\section{B. The Multicultural Education in America and Canada}

The multicultural education is a specific educational strategy in which the student's cultural background is viewed as positive and essential in developing classroom instruction and a desirable school environment. It is not a new concept in America because it has existed since 1920s when educators began writing about intercultural education and ethnic studies. The goal of multicultural education in America at that time was to make the dominant majority populations more tolerant and accepting toward first and second generation immigrants to maintain national unity and social control. (Montalto, 1978) The American multicultural education is based on the following beliefs: (1) The U.S. culture has been fashioned by the contributions of many diverse cultural groups into an interrelated whole; (2) Cultural diversity and the interaction among different groups strengthen the fibre of U.S. society; (3) Teachers and other professional educators must assume a leadership role in creating an environment that is supportive of multiculturalism. (Bidol et al. 1977) In most of American schools, they develop effective instructional strategies to implement the essential principles of multicultural education; they pay more attention to the cultural democracy, instilling the ideology of racial, gender, and status equality into the students' minds; they advocate promoting students' critical thinking, pursuing cooperative learning strategy. From 1982 to 1992, the school reform cycle occurred. However, the reformers and critics were more concerned with furthering their own professional career and winning election, which resulted in the poor progress in education. Nevertheless, many educators and researchers developed some powerful intervention strategies to integrate schools and their communities into a cooperative, supportive endeavour, helping to initiate a program of accelerated learning over 700 schools. With the ideology of cultural pluralism popularized among Americans, the multicultural democracy started to reform the school system, the multicultural education being the focus of the reform which monitored the achievement of all groups including language minority, ethnic minority, social class, and gender, making specific curricular assessment, and faculty recruitment plans for language acquisition. In 1990s, bilingual education helped the immigrant student to succeed. The educational practices turned out that multicultural education was a necessary response to the growing diversity in the nation like the United States. This educational ideology taught students to respect and value diversity, to cherish and empower their own communities. The school administrations seeked to improve the efficiency of the current system, leaving sexism, racism, and class privilege intact. The educators built trust and solidarity with the parents, the students, and the communities across cultural boundaries. Teachers entered the school improvement struggle, assisting their students from different minorities in finding their own identities, their cultural roots, and achieving academic success in the unfair world.

Multicultural education is carried on among all the Canadians involving diverse ethnic groups, language groups and religious groups for the purpose of promoting mutual respect for all the citizens. The early educational system checked the features of minorities and thus reflected a small number of minorities who contributed to the Canadian building. Conversely, the multicultural education stressed various cultural traits of diverse peoples and their unique contribution to the Canadian society. Every school is an element of multicultural society, which helps the students to find out the real content of this colourful society, educating them to build a more brilliant future together. Generally speaking, there are 
two levels of multicultural education in Canada: social education and school education. The former one focuses on the macro educational policies or programs, and the educational activities held by the social organizations, while the latter one includes two parts, the overt education in the classroom activities, and the covert education in after-class activities. From the perspective of macro environment, the social multicultural reality existed in Canada is a kind of educational factor which definitely contributes to mutual understanding and common learning. This is an imperceptible multicultural education, just like the spring breeze and rain to change the natrual world softly. The school teaching system transmits and develops multiculturalism, cultivating the students' multicultural awareness. In terms of textbooks compiling, the Canadian educational institutions try to compile the teaching materials reflecting racial, cultural and regional differences and advantages. Compared with the social education, the school multicultural education is more systematic and convergent. The multicultural contents are integrated into regular courses, for instance, the curriculum in Ontario contains wide range of multicultural contents, from the origin and building of Canada, the western development and social change in the courses of Grade 7 and 8, to the tolerant values, cultural tradition, cultural conflicts and coping strategies in the courses of Grade 9 and 10. As a matter of fact, the multicultural education is a constant process of cultural immersion in which the students are gradually cultivated to think in multicultural perspective, learning to appreciate and respect the cultural traditions and values of other ethnic groups.

\section{A Case Study of Multicultural Education in Liaoning Police Academy}

Although multicultural education is an exotic term, the principle and the practice of multicultural education have been the important components of ethnic educational progress in the whole area of China, especially in the minority areas. With more and more minority students coming from the southwest and northwest parts to the inland higher education institutions, the multiethnic diversity and multicultural education grow to the focus of attention in the university accepting minority students. How to provide them with high-quality educational programs and management strategies to live up to the practical and unique requirements of the minority students is the major task and the critical challenge for the administrative departments and classroom teachers in these universities. The paper is going to illustrate these issues from two perspectives.

\section{A. The Supportive Foundation of Multicultural Education: The Macro Administration}

The educators in minority areas excel in multicultural education thanks to the long-history reality of multiethnic integration and interaction. Whereas, teaching professionals in the inland university (Minzu University of China is exceptional) are mostly unfamiliar with minority education, even knowing nothing about ideology and methodology of multicultural education. For all that, the main administrative department of Liaoning Police Academy set us a good example to explore management strategies and priority policies concerning 100 minority students from Xinjiang Uygur Autonomous Region.

In order to respond to the call of Ministry of Education which proposes that greater efforts should be exerted to support Xinjiang minority education in Twelfth Five-year Plan, increasing the number of inland college students from Xinjiang minority areas, the administrative departments concerned in Liaoning Police Academy made adequate preparations for greeting and arranging for 100 minority students who finished their one-year preparatory courses in the School of Education, Ningxia University. A special department entitled Western Teaching and Administrative Office was set up, and a minority administrator from Xinjiang Police Academy was invited specifically for coordinating minority students' work. According to the author's statistical data collected from outside campus network of Liaoning Police Academy, there are three important news regarding Xinjiang minority students among 69 items, and 18 campus dynamic news among 304 news from Sep. 21, 2011 to Dec. 18, 2012. Luxin, the Vice Minister for Ministry of Education has visited these newly-admitted college students from Xinjiang for two times, conveying the great care and active encouragement for minority students. These freshmen from Xinjiang are responsible for promoting national solidarity, maintaining the harmonious stability of the country, and protecting the healthy development and social order through working hard in the academy. Figure 1 is the report of Luxin's addressing the minority students after the opening ceremony of national teaching contest for 34 police academies on Aug. 8, 2012.

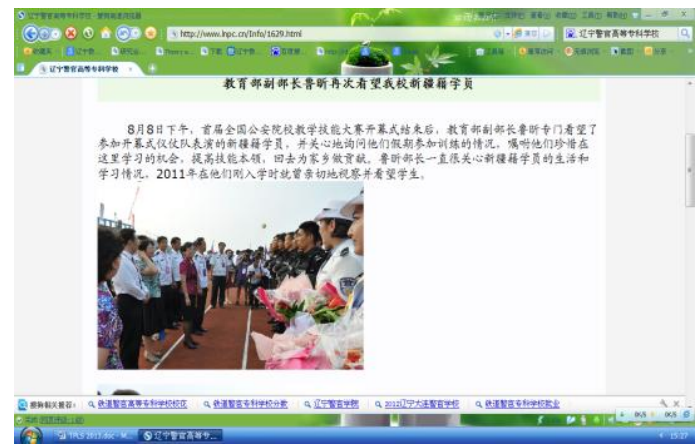

Figure1: Luxin, Vice Minister of Ministry of Educaiton, addressed the minority students from Xinjiang. 
During these two years, whenever the important festivals of Islam came, such as Kurban Festival and Fast-breaking Festival, the chief leaders took active part in their celebrations. Figure 2 is the group photo taken in the Muslim Dining Hall immersed in a festival atmosphere. They tasted the Muslim festive dishes; they piped up and danced; they enjoyed their traditional and cultural celebration with other ethnic brothers, which in itself reflected the fact that multiethnic integration and mutual understanding could be realized through frequent contact and equal communication sincerely and consciously. Besides the festive gathering, the administrators and the class teachers adopted more responsible attitudes towards these minority students, opening special remedial classes in English and Chinese in view of their weak knowledge in these two subjects and relatively difficult textbooks. Abundant recreational activities attracted talented minority students to take part in dance and song competition, and even yearly English Speech Contest. Admittedly, Liaoning Police Academy has become an epitome of conducting multicultural education actively from the macro perspective, and the positive atmosphere of mutual respect and multicultural understanding on the campus has been shaped.

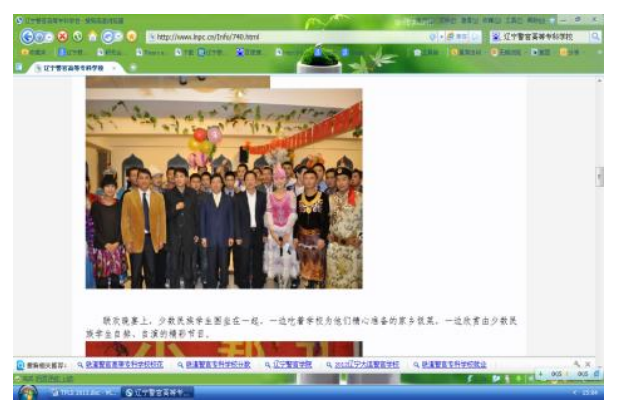

Figure 2: Celebration of the Kurban Festival in Liaoning Police Academy on Nov.8, 2011

\section{B. The New Concept and Pattern of Multicultural Education in and after English Class: The Micro Teaching Activity}

Fortunately, the author, as a researcher of multicultural education for more than 8 years, encountered nearly 20 minority students in her English class for the first time in September 2011, which offered her a stage to practice the principles of multicultural education and display educational strategies in a unique way with Chinese feature. In reality, the police academy as a semi-military administration college tends to focus on military training rather than build cultural atmosphere, especially multicultural atmosphere. However, owing to the integration of these minority freshmen into our campus and into our English class, the author actually devised different English plans to be compatible with the new ingredient in this multicultural class.

A suvey on cross-cultural communication learning requirements: the author's project of Cross-cultural Communication Competence through Network and Field Training (No. WYYB110088) in Liaoning Province was undertaken from September 2011. At the beginning, the author conducted a survey on the students' learning requirements and recommendations. There are 70 effective questionnaires. According to their answers, there are 62 percent of the total subjects who aren't familiar with this newly-developed discipline: Cross-cultural Communication; 62 percent consider this discipline has close relation with their future police career; 68 percent take teacher's instruction and network self-study as the most effective way to learn this discipline; the subjects who are interested in American, English and Canadian cultures account for 22 percent, 22 percent and 19 percent respectively; 89 percent consider their present English competence cannot help them fulfill the task of cross-cultural communication; 67 percent and 54 percent of the total subjects hope to improve their cross-cultural communication competence through selective course and field training. This survey reflects the concept of equality promoted by multicultural education. The teacher and the students are equal partners in the process of education, so the teacher must respect and listen to the voices and suggestions of the students, giving them some power to make decision. On the basis of the first-hand analytical data, the author can devise appropriate teaching plan for English class to meet the needs and arouse the interests of the students so as to realize the actual purpose of multicultural education.

Basic principles to follow in multicultural English class: it is really a challenge for the author to teach college English to the students from five peoples including the Han nationality (72 percent of the total students), the Uygur nationality (10 percent), the Mongolian nationality ( 5 percent), and the Kazak nationality ( 3 percent). In order that every one in the classroom could get equality and respect, the author made it clear to all that this English classroom is a typical multicultural classroom where equal respect and participation among all classmates are ensured. In the first class, the author delcared the following principles: (1) to respect all the students, and every student is encouraged to participate into the class activities equally; (2) to respect all the students' languages (though English is the main language in use), and they can use their native tongues if necessary; (3) to promote multiethnic cultural exchange and understanding through regular cultural introduction and interaction; (4) to enhance the students' cross-cultural communication competence by intentional teaching and training in and after English class.

Creative multicultural teaching plan for English class: in order to help students enhance their basic multicultural abilities in a relatively short period, the author spent one term on introducing the theoretical foundation of cross-cultural 
communication, the basic framework of the Western culture, the Han culture, and the Muslim culture, carrying out adequate practices of intercultural communication.

Unique warm-up activities: the main task for an English teacher in a multiethnic classroom is to attract the attention of all the students just at the beginning of the class. Thus, it is vital to devise the warm-up activity with ethnic peculiarity and cultural diversity. The author paid attention to different cultural and linguistic features, taking every cultural trait into account. The Muslim religion and cultures are unfamiliar to most students of the Han nationality, so the author gives priority to the introduction of Muslim culture. For example, the origin, the ceremony, and the modern features of Kurban, Fast-breaking and Nulusi Festival were introduced to the students as the first cultural stop of the Cultural Journey Series to bring students from different ethnic groups closer together through understanding "the other culture" with respect and appreciation. The author specifically made a series of PPTs entitled Cultural Journey Series including Muslim culture, traditional culture of the Han nationality, and of course, the Western culture. Figure 3, and Figure 4 are some of PPTs that the author used in the first part of English class as Knowing Other Culture warm-up activities. Apart from these attractive PPTs with texts, pictures, and videos, the author adopted various approaches to transmit colourful cultures, such as ask-and-answer approach (teacher-to-student interaction), case study approach (text discussion), and individual introduction approach (student-centered speech). When we were learning the Mongolian culture, the student Bazhen from Mongolian nationality came forward bravely and confidently. He introduced the origin, the function, and the significance of Obo. It was the first time for us to know that Obo was used for counting the number of the dead soldiers after the battle. When the soldier left for the front, he would put one stone on a fixed place on his tribal boundary. This heap of stones was erected strikingly on the endless grassland. Once the battle was over, the fighters came back to take away the stones, and the left ones indicated how many fighters had died upon the battlefield. But today Obo is full of fertile essence besides the markings of roads and boundaries, intended to worship the residence of the spirit. Although the number of Obo has declined recently, its symbolic meanings and spiritual guidance are promoted excessively. It will become the symbol and inner resources of Mongolian nationality. Bazhen's typical historical and cultural introduction regarding his nationality is only one of approaches that the author used as the unique warm-up activities. Once the student could fulfill this task in English, then he or she would use English. If it was difficult for them to introduce their history or culture in English, then they could choose Chinese. At last, the author would try to translate their main ideas into English in order to realize the goal of approaching the culture through English learning.

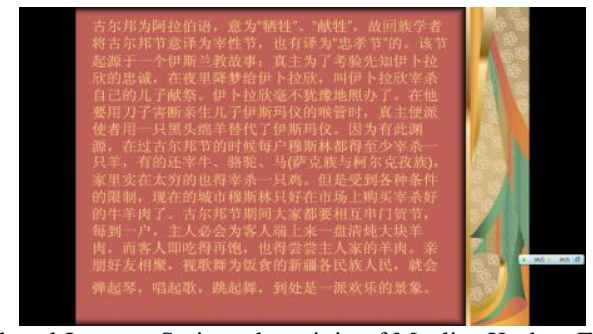

Figure 3: The Cultural Journey Series: the origin of Muslim Kurban Festival in Chinese.

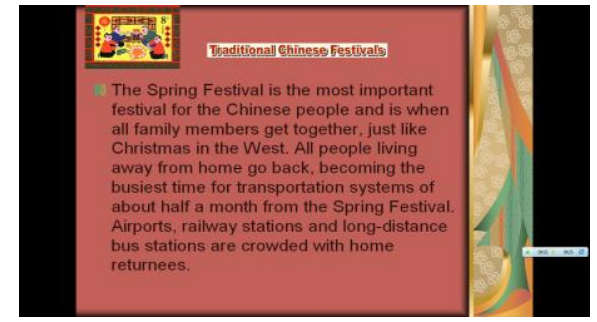

Figure 4: The Cultural Journey Series: the introduction of Chinese Spring Festival in English

Native American's cultural nurturing: the author concentrates on the Canadian Studies, especially the Canadian Aboriginal studies, so she can provide the students with plenty of Aboriginal cultural resources in and after English class as an important ingredient of cross-cultural communicaiton training. The electronic edition of her newly-published book entitled On the Status Quo and Development Policies of the Canadian Aboriginal Peoples was uploaded onto Multicultural Education and Policing English Network and Field Training Platform. Thus, the students could have a brand-new perspective to understand native Americans including their colonial history, their long-standing tradition, their splendid cultures, their honorable values and morals, and their scientific vision and sense. Furthermore, the author introduced her American Indian friend teaching in Liaoning Normal University to the students through reading her papers and sharing their exchanged E-mails. These E-mails are good examples to reflect the real experience of crosscultural communication between a Chinese and an American Indian, which assists the students in having keen insights into the native American's inner hearts. The following is one of Linda's E-mail to the author, and you must marvel at an American Indian's seriousness in her work and faithfulness to her friend. This is the positive cultural exchange and 
meaningful spiritual communication from which all of us can enhance our mutual understanding and cultural awareness, promoting international and interpersonal friendship.

09:53, Nov. 4, 2011, Friday

Dear Vicky,

Thank you for sending the picture--it is a good one! I did enjoy the conference so much, it was a great success.

Also, I've reviewed your PPT again and am so impressed. I don't see anything about it that needs to be changed, in particular. It is a great introduction to the culture; one thing to watch for: separate the American Indians from the First Nations People of Canada. While the borders were artificially created by governments, and the native peoples flow back and forth readily across the borders, they do by now identify themselves by these different name categories. Actually, all native people identify themselves by their tribal names rather than by the artificial designations that the two governments hav imposed upon them. But for most purposes, either the terms "American Indian" or First Nations" is appropriate. The other indigenous group in Canada is the Inuit. I have a whole slide show of Inuit pictures from the Arctic Circle that I present. I was the founder and organizer of a cultural to cultural and spiritual to spiritual project called" Journey to the Arctic's People" for a good number of years. We sent four teams over a four year period to the Arctic Circle. Someday, I'd love to go back.

Another thing I'm puzzled about: in the U.S. and Canada, we do not refer to ourselves as Aboriginals... To me, an aboriginal is from Australia or New Zealand and represents a specific group of people. I have a minor degree in Anthropology too, and never remember any other groups being identified as aboriginal... am wondering if this is a Chinese characteristic? Did the Canadian professors who were in attendance at the conference identify First Nations people as aboriginals? No American Indian ever uses that term as a means of identification... so this is a puzzle. I know that Professor Wang (Lily) uses the term, as well. We have discussed it a bit. Even in China, you refer to your ethnic groups as "ethnic" instead of aboriginal. Can you solve this mystery for me?

Vicky, you just have no idea that feelings it gives to me to see a PPT on North American culture, with Chinese characters!! I have several professor friends in Canada who would love to see your PPT and would enjoy it so much. Just the idea, the thought, that a few Chinese academics are interested in the native culture in North America is delightful, validating, and empowering.

Your classes sound wonderfully diverse. Perhaps sometime I can visit one of them? You mentioned the remote frontier--it is my heart's desire to go there before I have to leave China (which should be a couple of years away, at least. I will stay as long as I can).

Also, I want to send you Kevin Locke's bio with pictures but must find it first. While I'm looking for it, I'm going to share with you an American Indian funeral PPT. Your help with 'our' Locke project is greatly appreciated. I have a number of American Indian books you can borrow, if you want to.

Best, have a good weekend,

Linda

The American Indian funeral PPTs attached to this letter were appreciated and commented by the students. This was an intuitive way to know about the culture of the native American's formal funeral ceremony. In the PPT of A Wake for An Indian Warrior, he (the dead marine) earned the eagle feather from his people, and the wake services were held for three days in order to pay respects to this 21 year old Marine who was killed in Iraq on January 14, 2006. An eagle feather rested on his body and the mournful tune of organ and bagpipe reverberated among all the grave pictures. Our students learnt a vivid cultural lesson through watching and tasting every section of funeral procession with detailed text explaining, multidimensional pictures displaying, and background music ringing. Figure 4 exhibits the last segment of the funeral process: As a Lakota, the Marine was honored during a three day wake service at the Little Wound School in Kyle, SD.

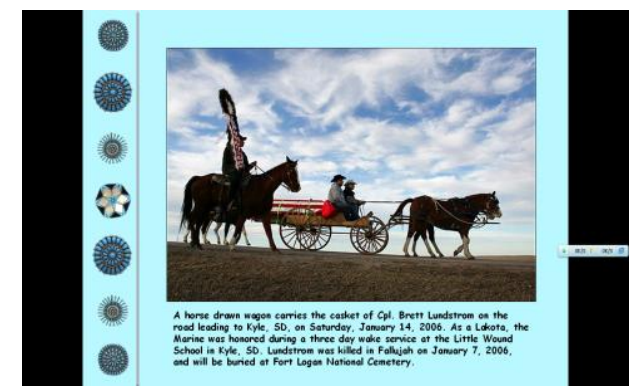

Figure 5: The American Indian's funeral procession "A Wake for An Indian Warrior".

Diversified and colourful after-class activities: the author not only devised creative and attractive multicultural English class, but also expand the students' English learning space after English class. These fortunate students can exchange ideas, share cultural fruits, and get cultural immersions by means of taking part in the Growing-up (an English QQ group, Figure 5 gives us the communication recording of group members on Dec. 31, 2012) activities, and logining into the learning platform of Multicultural Education and Policing English Network and Field Training Platform which has adquate cultural and English resources including several course wares of the author's cultural books, the classical 
English movies and E-books representing cultural differences and traits, the virtual platform for cross-cultural communication practice in English. On all accounts, the students can find various opportunities online or offline to fulfill their destinies of understanding the other cultures and their own cultures via English tool. Apart from that, the author also encouraged her students to take part in the performance of the play adapted from a text in Intensive Reading, Book 3. It was about the intense contradictions between the father and his three children due to generation gap. 12 students took part in the three-act performance after careful and repeated rehearsals, and other 27 students enjoyed watching, thinking deeply about the cultural conflict due to the concept differences. Figure 6 is one of the pictures taken in the second act happened in the dining room. This performing activity through students' personal participation can not only arouse their desires for learning English language, but also increase multiple opportunities to touch and experience the culture itself behind the language, which constitutes the cultural essence.

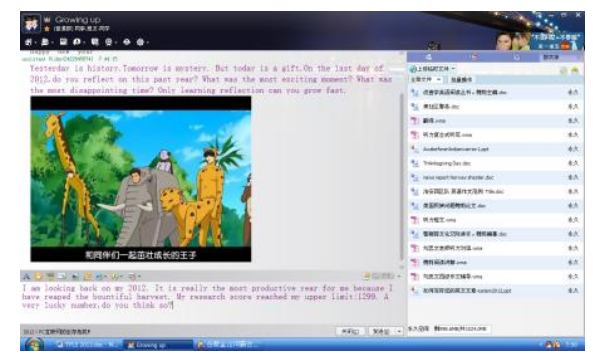

Figure 6: The Growing-up QQ Group activities on the last day of 2012. On the right is the list of uploaded materials of multicultural education.

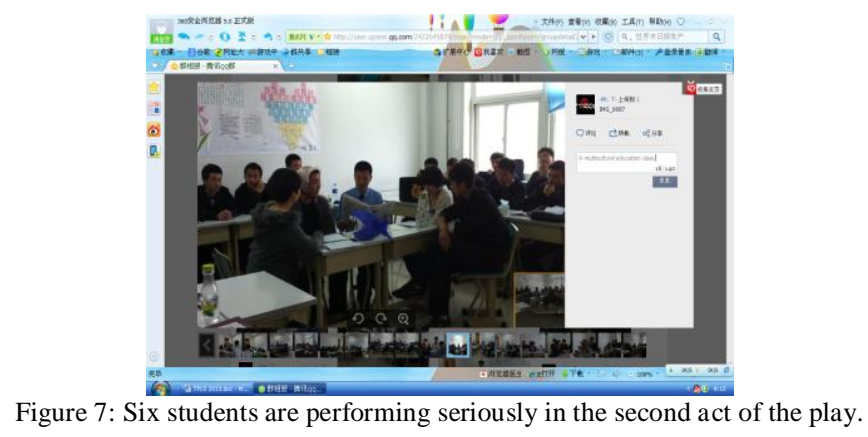

\section{CONCLUSIONS}

The multicultural education has become the educational reality and common consensus around the world along with the Global Village forming. Undoubtedly, interpersonal communication regardless of race, ethnic group, nationality, gender, and cultural background will become prevalent and universal. In view of this mega trend, every world citizen is responsible for learning and understanding the other culture through formal multicultural education in school or informal self-study through other different approaches. The English teacher, functioning as the cultural bridge, has the inescapable duty to transmit the best of the Eastern and Western cultures. The integration of multicultural education into English class is the best combination. The author's creative English plans for students coming from different peoples offer them precious opportunites to proudly present their own cultural heritages in front of the classmates who are unfamiliar with their traditions and cultures. It has been proved that the author's creative ideas and persistent practices achieve the great success. 20 minority students from Xinjiang are very satisfied with one and half years' English learning in Liaoning Police Academy because they can maintain their self-confidence and introduce their ethnic cultures to the Han students, and meanwhile, they can learn a lot of Chinese traditional cultures and Western cultures through English immersion. For the majority students, they also reap bountiful harvest in cultural garden. They have deep understanding of minority cultures owing to personal communication with minority classmates and systematic cultural learning in and after English class. This is an exceptional harvest on the campus. In reality, this is only the beginning for the author to carry out the multicultural education. As the accumulation of the educational experiences and reflection upon its strengths and limitations are continuously enriched, the author's multicultural plan in and after English class will be more effective, diversified and fascinating.

\section{ACKNOWLEDGMENT}

The author wishes to thank the experts and judges of the Education Department of Liaoning Province for their support of The Twelfth Five-year Plan for Educational Science project of Liaoning Province (2012) No. JG12EB082J: Construction of Seamless Foreign Language Learning and Interactive Cyberspace via Tencent Software. 


\section{REFERENCES}

[1] Banks, J. A. (1981). Multiethnic education: Theory and practice. Boston: Allyn \& Bacon.

[2] Bidol, P.,et al. (1977). Incorporating a multicultural perspective: NCATE's revised standards for curriculum. Unpublished manuscript, American Association of Colleges for Teacher Education.

[3] Cardozo, Andrew and Louis Musto (eds.). (1997). Battle Over Multiculturalism: Does It Help or Hinder Canadian Unity. Ottawa: Person-Shoyama Institute.

[4] Fleras Augie and Jean Leonard Elliott. (1999). Unequal reations: an introduction to race, ethnic, and abdominal dynamics in Canada. Scarborough, Ontario: Prentice-Hall Canada, Inc.

[5] Goodenough, W. (1976). Multiculturalism as the normal human experience. Anthropology and Education Quarterly, 7 , November, pp.7-18.

[6] Hoopes, D.S. (1979). Intercultural communication concepts and the psychology of intercultural experience. In M. D. Push (Ed.). Multicultural education: A cross-cultural training approach. LaGrange Park, III: Intercultural Network, pp.9-38.

[7] Montalto, N. V. (1978). The forgotten dream: A history of the intercultural education movement, 1924-1941. Dissertation Abstracts International, 39A, 1061. University Microfilms No.7813436.

[8] Wei Li. (2012). On the status quo and development policies of Canadian Aboriginal peoples. Shenyang: Liaoning Ethnic Publishing House.

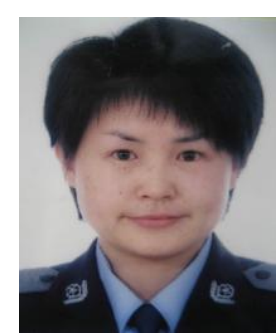

Li Wei: Born in Feb. 1972 in Liaoyang, China. BA of English, Liaoning Normal University, 1993, Master of English, Liaoning Normal University, 2007. She is an associate professor in Liaoning Police Academy; the author of one EI indexed paper and nine international papers. She has published more than 40 papers in Chinese academic journals including World Ethno-national Studies, Shandong Social Sciences, Social Sciences in Xinjiang, Academy. Her concentration centers on the Multicultural education, the Canadian Studies and Foreign Language Teaching with computer and network assistance.

Professor Wei is a candidate for the Police Liaison Officers of the Public Security Ministry of China. 